\title{
FIRST RECORD OF DOWNY MILDEW OF QUINOA IN EGYPT
}

\section{EL-ASSIUTY, ELHAMY M., FAWZIYA M. BEKHEET and ZEINAB M. FAHMY}

Plant Pathology Res.Inst., ARC, Giza

(Manuscript received 25 September 2014)

Quinoa (Chenopodium quinoa Willd.) is a grain crop grown primarily for its edible seeds. The plant has originated in the Andean region of South America, where it was domesticated 3,000-4,000 years ago for human consumption. Because quinoa has a high nutritive value and desirable agricultural traits as tolerance to drought and salinity, it has gained increased demand in recent years. The winter climate in Egypt favors good production of quinoa and it has already been cultivated in saline soils in Upper Egypt. More, recently in 2014, downy mildew was recognized in plants of two Egyptian quinoa trials at Giza and Ismaeliya governorates. Infected plants showed small to large irregular chlorotic lesions with grey mildew on leaves (Fig.1), often leading to early leaf defoliation. Light microscopy revealed presence of colorless dichotomously branched sporangiophores (2-3.2 $\mu$ width), slightly curved at the far point bearing hyaline sporangia (Fig.2). Spores are deciduous, mostly ovoid, 11.0$15.6 \mu \times 20.0-25.5 \mu$ (Fig.2). Dark brownish oospores were observed embedded into leaf tissues. The disease is caused by Peronospora variabilis Gäum, formerly Peronospora farinosa f.sp. chenopodii Byford, (Choi et al., 2010). It is expected that this disease could be a potential constraint for quinoa production in Egypt. To minimize the effect of downy mildew on the seed yield, in depth studies are to be done to develop control measures and accumulate information about disease parameters under local conditions.

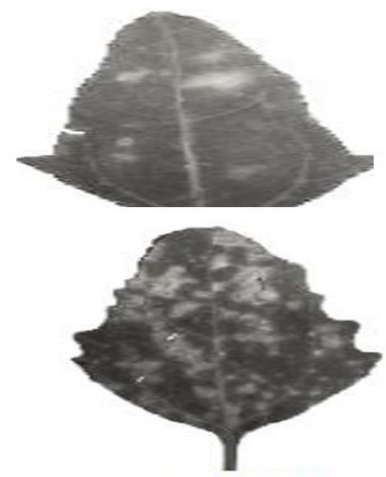

Fig.1.Quinoa leaves attacked by P.variabilis

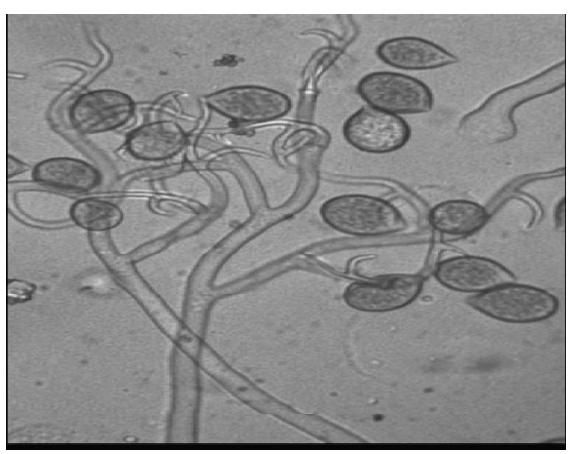

Fig.2.Sporangiophores and sporangia of P.variabilis (X 400)

\section{REFERENCES}

Choi, Y.J., Danielsen, S., Lubeck, M., Hong,S.B., Delhey,R. and Shin, H.D. 2010. Morphological and molecular characterization of the causal agent of downy mildew on quinoa (chenopodium quinoa). Mycopathologia, 169: 403-412. 


\section{التقرير الأول عن مرض البياض الزغبى

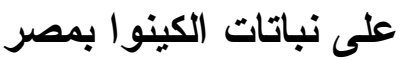

\section{الهامى مصطفى الأسيوطى - فوزية محمد بخيت

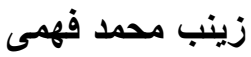

$$
\text { معهر بحوث أمراض النبات - مركز البحوث الزراعية - الجيزة }
$$

تعثبر منطقة الإنديز بامريكا الجنوبية منشأ للكينوا، حيث استخدمت منذ أكثر من ... باعام كغذاء للإنسان و الحيوان. ونظر القيمتها الغذائية العالية وصفاتها الزر اعية مثل تحملها للملوحة و الجفاف فقد اكتسبت الكينوا أهمية خاصة فى السنوات الأخيرة حيث أمكن زر اعة هذا المحصول تحت الظروف البيئية المختلفة من دول العالم. ويعتبر الموسم الشتوى ملائما للزراعة وإنتاج محصو لا عاليا من الكينو افى مصر حيث امكن زراعتها بنجاح فى بعض الحقول عالية الملوحة

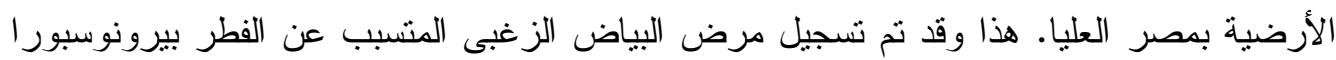
فاريابليز على نباتات منزرعة ضمن تجارب مقامة بكل من محطتى البحوث الزراعية بالجيزة

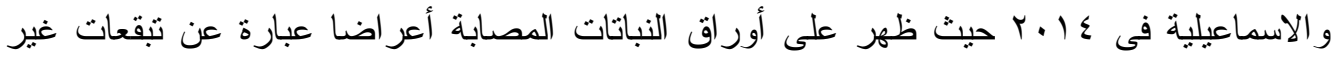
منتظمة رمادية اللون يظهر عليها زغبا مميزا للمرض سرعان ماتؤدى إلى تساقطها المبكر . وقد

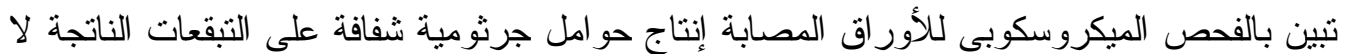
لون لها تتقرع تفرعات ثنائية عرضها ب-Y.r ميكرون منحنية الأطر اف تحمل جر اثيما سبور انجية

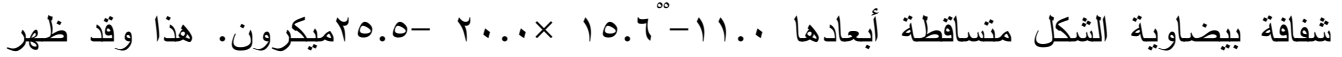
بالفحص الميكروسكوبى احتواء أنسخة الأوراق المصابة على الجراثيم البيضية للفطر المسبب. لذا

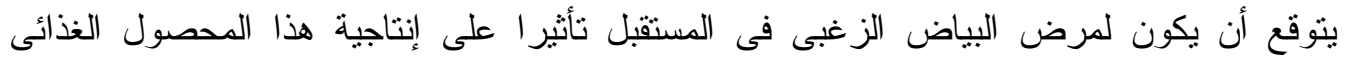

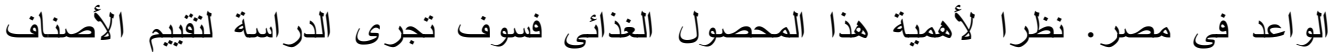
للإصصابة وطرق المقاومة للمرض. 